\title{
PERANCANGAN MOBILE GAME SEBAGAI MEDIA LITERASI KEUANGAN UNTUK REMAJA
}

\author{
Muhammad Fajar Rafif ${ }^{1}$, Asidigisianti Surya Patria ${ }^{2}$ \\ 1,2Desain, Fakultas Bahasa dan Seni, Univeritas Negeri Surabaya \\ muhammadfajarrafif@gmail.com ${ }^{1}$, asidigisiantipatria@unesa.ac.id ${ }^{2}$
}

\begin{abstract}
Abstrak
Hampir segala aktivitas manusia dipermudah dan dipercepat dengan smartphone, yang tanpa kita sadari telah mengubah perilaku masyarakat dalam berbelanja. Kemudahan transaksi digital telah membuat penggunaan aplikasi belanja daring meningkat. Sayangnya, hal ini masih belum diimbangi dengan pengetahuan dalam mengelola keuangan. Perlu adanya perancangan media untuk mengedukasi masyarakat mengenai pentingnya literasi keuangan. Tujuan dari perancangan ini adalah merancang mobile game untuk menyampaikan pembelajaran tentang keuangan kepada remaja secara efektif untuk menambah dan meningkatkan kesadaran mereka tentang pentingnya manajemen keuangan. Metode Perancangan terdiri dari tahap pengumpulan dan analisis data menggunakan model Miles \& Huberman, tahap perancangan konsep, tahap perancangan GDD (Game Design Document), tahap perancangan aset visual, tahap perancangan purwarupa, tahap uji coba dan validasi kelayakan media. Berdasarkan hasil ujicoba dan validasi ahli materi menunjukkan bahawa mobile game ini dikatakan layak.
\end{abstract}

Kata Kunci: game edukasi, literasi keuangan, mobile game, remaja

\begin{abstract}
Almost all human activities are facilitated and accelerated with the help of smartphones, without us knowing has changed people's shopping behavior. The flexibility of digital transactions has increased the use of shopping applications. Unfortunately, this has not been equal to the knowledge of financial management. A media design is needed to educate the public about the importance of financial literacy. The purpose of this research is to design a mobile game that can convey financial knowledge to teenagers and effectively enhance as well as increase their awareness about the importance of financial management. The design method consists of data collection \& analysis using the Miles \& Huberman Model, the concept design stage, the GDD (Game Design Document) design stage, the visual asset design stage, the prototyping stage, the testing, and the validation phase. From the testing and the validation phase, the results of the media expert's test got a value of 4.87 (very feasible), the results of the material expert's test got 4.5 (very feasible), and the test results against the intended end-user get a value of 4.68 (very feasible).
\end{abstract}

Keywords: education game, financial literacy, mobile game, teenager 


\section{PENDAHULUAN}

Smartphone mempermudah dan mempercepat aktivitas manusia yang tanpa disadari datang dengan dampak yang tak terduga. Kita menjadi lebih bergantung kepada smartphone untuk memperoleh gratifikasi instan, berharap segala aktivitas membuahkan hasil secepat dan semudah mungkin. Misalnya, melalui aplikasi jasa antar makanan, tinggal melakukan transaksi melalui aplikasi dan tanpa menunggu lama, makanan pun datang. Bahkan transaksi pembayaran bisa dilakukan dengan uang elektronik. Uang elektronik sendiri adalah alat pembayaran yang memiliki nilai uang yang tersimpan secara elektronik dalam suatu media elektronik.

Peningkatan penggunaan uang elektronik terjadi secara massif selama 3 tahun terakhir. Berdasarkan data Bank Indonesia pada tahun 2018 ke 2019 menjadi 5,5 milyar transaksi dengan nilai sebesar Rp 145,2 triliun. Data tersebut menunjukkan kemudahan proses transaksi keluar masuknya uang elektronik di Indonesia. Hal ini perlu diimbangi dengan pengetahuan yang tepat mengenai kemudahan proses transaksi ini keuangan. Pengetahuan dan kecakapan untuk mengaplikasikan pemahaman tentang konsep dan risiko, keterampilan agar dapat membuat keputusan yang efektif dalam konteks finansial untuk meningkatkan kesejahteraan finansial, baik individu maupun sosial, dan dapat berpartisipasi dalam lingkungan masyarakat disebut dengan Literasi keuangan (Tim GLN Kemendikbud, 2017).

Hasil survei Literasi dan Inklusi Keuangan yang dilakukan Otoritas Jasa Keuangan (OJK) pada tahun 2019 mengatakan indeks literasi keuangan masyarakat masih 38,03\%. Artinya hanya segelintir orang yang sudah memiliki pengetahuan untuk mengelola keuangan mereka (Otoritas Jasa Keuangan, 2019). Hal ini menandakan bahwa jumlah transaksi digital yang massif ternyata masih belum diimbangi dengan pengetahuan dalam mengelola keuangan. Ditambah dengan adanya pandemi COVID-19 dewasa ini juga telah mengubah perilaku masyarakat dalam berbelanja. Berbeda dengan transaksi konvensional yang berpotensi menular, kemudahan ruang digital untuk bertransaksi telah membuat penggunaan aplikasi belanja online meningkat sebanyak 300\% (Bisnis.com, 2020). Sehingga perlu adanya perancangan media untuk mengedukasi masyarakat mengenai pentingnya literasi keuangan agar masyarakat menjadi lebih bijak dalam bertransaksi secara digital, mengingat mudahnya proses transaksi di ruang digital.

Banyak media yang bisa digunakan untuk menyampaikan pentingnya literasi keuangan, hanya saja perlu pemilihan media yang tepat agar pesan yang disampaikan lebih memiliki dampak dan sesuai dengan target perancangan. Simulasi adalah metode pembelajaran yang cukup efektif. Dengan simulasi, materi pembelajaran atau objek yang abstrak (tidak nyata) bisa direpresentasikan menjadi konkrit (nyata), sehingga seseorang bisa merasakan langsung pengalaman yang sebenarnya tanpa harus takut adanya konsekuensi yang ada (Munir, 2012).

Pokkt, Decision Lab, dan Mobile Marketing Association (MMA) melihat adanya peningkatan jumlah peminat mobile game secara signifikan di Indonesia. Studi ini juga mengungkapkan bahwa bermain game adalah aktivitas yang paling sering dilakukan 
melalui smartphone, diikuti dengan bersosial media (Maulida, 2018). Mobile game dipilih sebagai media perancangan karena selain banyak peminatnya, mobile game bisa menampung segala bentuk interaksi yang diinginkan untuk membuat sebuah permainan simulasi secara praktis, mengatasi keterbatasan ruang dan waktu.

Demografi Indonesia menunjukkan bahwa yang paling sering berinteraksi dengan ruang digital adalah remaja umur 15-19 tahun, di mana 91\% dari mereka adalah pengguna ruang digital (Asosiasi Penyelenggara Jasa Internet Indonesia, 2018). Maka, tujuan dari perancangan ini adalah merancang mobile game untuk menyampaikan pembelajaran tentang keuangan kepada remaja secara efektif. Mobile game ini untuk menambah dan meningkatkan kesadaran mereka tentang pentingnya manajemen keuangan. Ruang lingkup perancangan mencakup perancangan game mulai dari tahap konsep hingga menjadi purwarupa game, yang kemudian akan diujicoba dan divalidasi kelayakannya.

\section{METODE PENELITIAN}

Metode Penelitian terdiri dari beberapa tahapan, yaitu tahap pengumpulan data, tahap analisis data, tahap perancangan konsep, tahap perancangan GDD (Game Design Document), tahap perancangan aset visual, tahap perancangan purwarupa, tahap uji coba, dan validasi kelayakan media. GDD adalah sebuah dokumen yang menjadi landasan dan panduan atas perancangan sebuah game. GDD adalah hasil kerja game designer dalam memberikan panduan desain game untuk kemudian dikomunikasikan dengan bidang lain, baik yang terlibat dalam proses pembuatan game secara langsung (seperti programmer, game artist, dan lain-lain) maupun tidak (seperti investor, game tester, dan lain-lain) agar mendapatkan gambaran game yang dirancang (GameLab Indonesia, 2018).

Pengumpulan data dilakukan untuk mendapatkan informasi yang dibutuhkan, lalu dianalisis secara kualitatif menggunakan model Miles \& Huberman, yang terdiri atas tiga aktivitas yang terjadi secara bersamaan, yaitu tahap reduksi data, penyajian data, dan penarikan kesimpulan (Miles \& Huberman, 2012). Pada tahap perancangan diperlukan data mengenai konten atau materi yang diperlukan dalam literasi keuangan. Data ini diperoleh dari hasil wawancara mendalam tidak terstruktur dengan ibu Ita Guntari, CFP selaku perencana keuangan untuk mendapatkan informasi seputar keuangan, dan cara mengemas materi keuangan ke dalam media yang dituju, serta rekomendasi materi keuangan yang cocok dan relevan untuk remaja. Sebagai referensi penunjang untuk pengembangan game diperoleh dari studi pustaka/literatur yang berkaitan dengan tahapan-tahapan pebuatan game.

\section{HASIL DAN PEMBAHASAN}

\subsection{Konsep Kreatif}

Ruang lingkup game adalah perencanaan keuangan, perencanaan dana darurat, dengan pengenalan investasi dan resiko yang relevan bagi remaja. Untuk memperkenalkan materi ini, media yang digunakan dalam perancangan ini adalah mobile game, dengan penyampaian materi melalui cerita seorang pemuda yang sedang berusaha untuk mengatur keuangannya agar dapat mencapai tujuannya. Perencanaan keuangan adalah 
hal yang sulit dijelaskan dan dipelajari hanya melalui tulisan, sehingga perlu adanya simulasi yang melibatkan peran dari pemain. Dengan melibatkan peran pemain, pemain bisa menerapkan ilmunya langsung secara aktif melalui simulasi, yang artinya ilmu akan lebih mudah dipahami daripada ilmu yang diterima secara pasif, karena pemain dapat merasakan langsung dampak atas pilihan yang dipilihnya di saat bermain. Selain itu, proses pembelajaran pun juga menjadi lebih praktis, karena dapat diakses di manapun dan kapanpun.

Genre (jenis game) yang dituju adalah gabungan antara Adventure Game dan Management Simulations, dengan menggunakan elemen storytelling ala komik untuk memberikan gambaran skenario bagaimana manajemen keuangan menjadi penting dan menggabungkannya dengan berbagai macam decision making seputar keuangan. Platform game yang dituju adalah Android, dengan sasaran perancangan adalah remaja usia 15-19 tahun yang bertempat tinggal di Kota Surabaya yang memiliki sifat konsumtif dengan literasi keuangan yang minim dan suka bermain game narasi.

Game mengambil setting zaman sekarang di Kota Surabaya dengan fokus cerita seputar kehidupan sekolah si Budi. Cerita dimulai dengan si Budi dalam kondisi kehabisan uang, dan meminta uang kepada ibunya untuk keperluan study tour yang bertepatan dua bulan (8 minggu) dari sekarang. Ibu Budi menolaknya, karena sesuai perjanjian awal masuk SMA, dengan uang yang diberikan ibunya setiap minggu, Budi harus secara mandiri mengatur keuangannya untuk kebutuhan hidupnya. Dua bulan ke depan Budi harus mengatur tujuan keuangannya agar dapat mengikuti study tournya, dengan mempertimbangkan kebutuhan lainnya juga. Penulisan naskah menggunakan jenis huruf Calibri pada seluruh naskah, dengan ukuran huruf seperti yang telah dicontohkan pada panduan penulisan ini. Jarak spasi adalah single dan isi tulisan atau naskah menggunakan perataan kiri-kanan (justified).

\subsection{Mekanisme Game}

Mekanisme utama permainan berupa memperbaiki kondisi keuangan pemain dan memenuhi kebutuhan sehari-hari pemain dengan cara memilih secara tepat satu di antara sekian aktivitas yang disediakan. Saat pemain mulai menjalankan game, pemain dihadapkan dengan menu utama, di mana pemain bisa memulai permainan, mengubah opsi permainan, melihat informasi tentang game, dan keluar game. Saat pemain memulai permainan, pemain akan dihadapkan dengan skenario cerita awal, dilanjutkan dengan tampilan tanggal yang merepresentasikan waktu dalam game. Tampilan tanggal ini muncul di tiap hari, yang kemudian dilanjutkan dengan kegiatan sekolah. Tiap harinya setelah pulang sekolah, pemain bisa memilih satu kegiatan yang bisa dilakukan, yang dapat mempengaruhi keuangan karakter pemain. Tiap minggu karakter pemain akan memperoleh sejumlah uang saku untuk digunakan. Aktivitas ini akan berlanjut sampai pemain mencapai minggu ke-8, untuk kemudian ditentukan apakah pemain menang atau kalah, berdasarkan mampu tidaknya pemain dalam membayar uang study tour.

Sistem awards (penghargaan) digunakan untuk mendorong pemain agar tetap tertarik dalam bermain melalui beberapa tantangan opsional yang bisa dicapai, misalnya 
mengakumulasi uang dua kali lebih banyak daripada biaya study tour. Tiap tantangan dirancang dengan tujuan meningkatkan kemampuan decision making keuangan pemain lebih jauh, sehingga membuat pemain merasa dihargai atas kemahirannya dalam bermain. Leaderboard (papan peringkat) digunakan untuk mendukung sistem awards, di mana leaderboard menampilkan peringkat pemain berdasarkan banyaknya awards yang diperoleh, memacu pemain agar terus mengembangkan kemampuan mereka melalui persaingan antar pemain.

Dalam membuat game, penting untuk merancang bagaimana game nantinya akan berjalan. Flowchart atau diagram alir adalah suatu bagan diagram dengan simbol-simbol grafis yang menyatakan aliran prosedur sistem secara detail. Flowchart menggambarkan cetak biru langkah kerja suatu program sebelum program tersebut mulai dikerjakan/dibuat (Pratama, 2017). Berikut ini adalah rancangan Flowchart game secara garis besar.

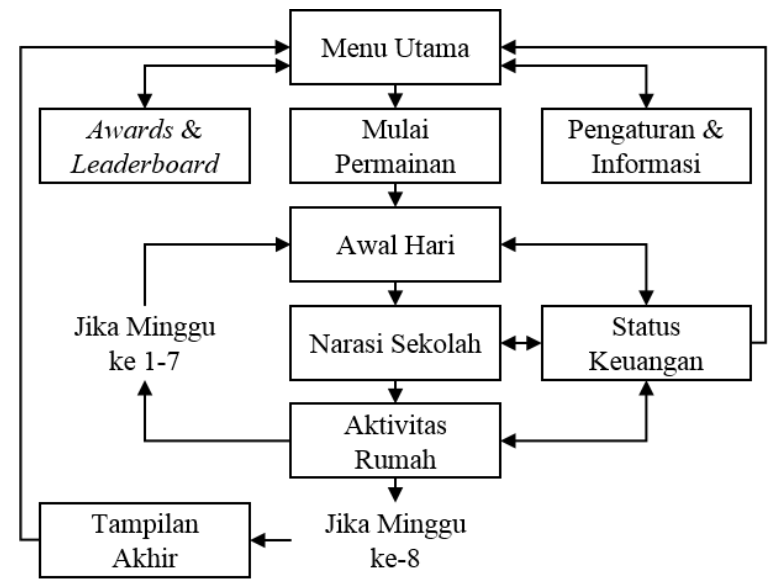

Gambar 1. Bagan Alur Game

[Sumber: Dokumentasi Penulis]

\subsection{Konsep Visual}

Estetika adalah faktor yang perlu dipertimbangkan dalam pengembangan game. Pertimbangan arah visual game adalah salah satu langkah untuk membuat pengalaman bermain menjadi lebih berkesan dan lebih dapat dinikmati. Visualisasi game yang bagus dapat menggait pemain untuk memainkan game dan dapat membuat setting game terlihat nyata. Visual game yang bagus juga dapat mendukung kualitas elemen lain pada game seperti mekanisme dan narasi game. Selain sebagai visual dalam game, visual juga berperan dalam proses perancangan game itu sendiri. Ilustrasi dapat memperjelas arah desain game karena desain game yang hanya tergambar di pikiran seseorang bisa jadi berbeda dengan desain game yang tergambar di atas kertas. Purwarupa Antarmuka yang digambar di atas kertas dapat memperjelas kelayakan antarmuka. Sebuah concept art (konsep ilustrasi) yang bagus juga dapat memberikan inspirasi terhadap visi game yang dikehendaki. Dalam proses mengolah desain game yang abstrak menjadi game yang bisa dimainkan, ilustrasi bisa menjadi langkah yang tepat untuk memberikan pondasi yang kuat terhadap game yang akan dibuat (Schell, 2008). 
Warna memiliki peran yang penting dalam game. Tiap warna mengkomunikasikan pesan tertentu, dan apabila digunakan dengan tepat, warna bisa memperkuat pesan, tema, dan suasana game yang ingin disampaikan. Selain sebagai estetika, warna juga bisa berperan sebagai petunjuk, baik dalam bentuk arahan maupun sebagai pembeda antara 1 elemen dengan lainnya, sehingga bisa membantu pemain dalam bermain (Tulleken, 2015). Untuk menghasilkan kesan yang fun dan santai, gaya visual yang digunakan yaitu visual yang sederhana, dengan menggunakan pattern warna yang terbatas pada warna jingga untuk memperkuat identitas visual game. Ilustrasi dikemas ke dalam panel-panel, sehingga terlihat seperti komik. Teknik ilustrasi menggunakan teknik vector dengan pengaplikasian shading minim yang dibubuhi line-art, sehingga menghasilkan style seperti pada Game Florence. Dalam perancangan menggunakan tema warna yang memberikan kesan ceria dan hangat. Game akan menggunakan warna jingga berdampingan dengan penggunaan warna netral seperti putih dan abu-abu.

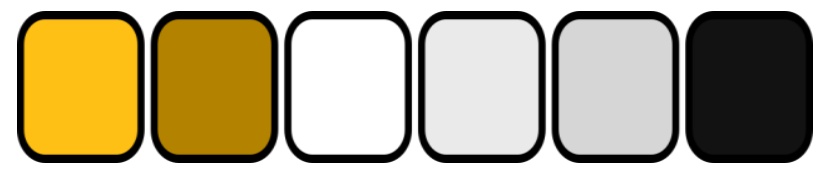

Gambar 2. Palet Warna Game

[Sumber: Dokumentasi Penulis]

Judul game yang dirancang adalah "Celengan si Budi". "Celengan" di sini bisa diasosiasikan dengan kegiatan menabung dan sesuatu yang berkaitan dengan uang, yang erat kaitannya dengan kegiatan utama yang akan dilakukan selama bermain. "Si Budi" adalah karakter utama game ini. Selain itu, Budi adalah nama yang umum dan mudah diingat. Dengan judul "Celengan si Budi", tanpa mencobanya terlebih dahulu pemain sudah bisa mendapatkan gambaran umum tentang game ini, yaitu game seputar keuangan. Judul game yang sederhana membuatnya mudah diingat oleh pemain, karena menggunakan objek yang berkaitan dengan aktivitas pada game, dan menggunakan nama individu yang umum. Dan sejauh ini belum ada game dengan judul serupa.

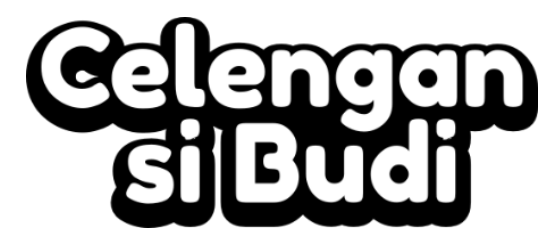

Gambar 3. Judul Game

[Sumber: Dokumentasi Penulis]

Pemilihan dan penataan huruf yang tepat akan mempengaruhi kualitas penyampaian pesan kepada audience (Landa, 2011). Dalam perancangan menggunakan huruf Sans Serif dengan bentuk garis yang bulat untuk membawakan kesan santai. Font Fredoka One untuk teks headline. Body text (teks paragraf). Font Sniglet Regular, karena selain memiliki tingkat keterbacaan yang tinggi, font juga memiliki kesan santai. 
1234567890

abcdefghijklmnopqrstuvwxyz ABCDEFGHIJKLMNOPQRSTUVWXYZ
1234567890

abcdefghijklmnopgrstuvwXyz ABCDEFGHIJKLMNOPQRSTUVWXYZ

Gambar 4. Font Fredoka One dan Font Sniglet Regular

[Sumber: Dokumentasi Penulis]

\subsection{Proses Perancangan}

Proses perancangan diawali dengan perancangan dan penulisan konsep game sehingga memberikan gambaran secara garis besar mengenai mekanisme game dan kebutuhan aset visual pada game, yang kemudian dilanjutkan ke tahap perancangan GDD (Game Design Document) menggunakan platform web Notion. Berdasarkan GDD yang telah dirancang, langkah selanjutnya adalah menentukan (membuat list) objek, elemen visual, dan desain antarmuka yang akan divisualisasikan. Setelah daftar aset visual dibuat, langkah selanjutnya yaitu penggambaran beberapa sketsa alternatif gambar di kertas untuk setiap aset visual yang dibutuhkan, untuk kemudian dipilih satu alternatif yang paling sesuai.

Langkah selanjutnya adalah tahap pembuatan aset visual berdasarkan satu alternatif yang dipilih secara digital menggunakan perangkat lunak Inkscape sehingga menghasilkan satu aset visual final. Untuk perancangan desain antarmuka langkah pertama yang dilakukan adalah membuat wireframe antarmuka secara digital menggunakan perangkat lunak Inkscape, untuk kemudian diolah lebih detail sehingga menghasilkan satu desain antarmuka. Langkah tahap pembuatan aset visual dibarengi dengan tahap perancangan purwarupa game menggunakan perangkat lunak Game Maker Studio 2. Aset visual yang sudah jadi akan diorganisir terlebih dahulu sebelum dimasukkan ke dalam purwarupa, menggantikan aset visual placeholder. Setelah purwarupa siap diuji coba, purwarupa akan dijadikan file Android Application Package (APK) untuk kemudian diuji coba ke smartphone lain. File APK game Celengan si Budi bisa diunduh di https://cutt.ly/celengan_si_budi.

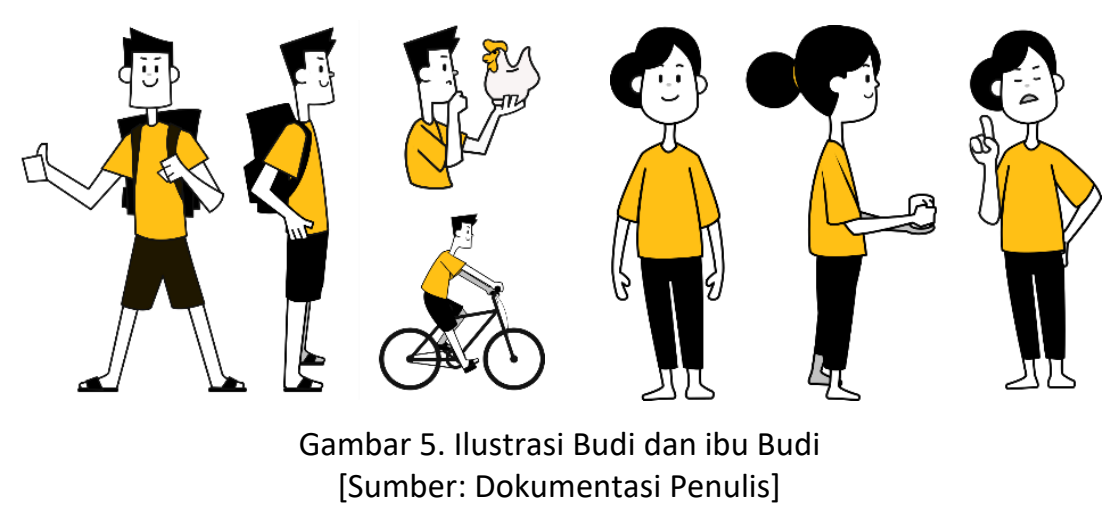

Budi adalah karakter utama dalam game ini. Pemain akan berperan sebagai Budi selama bermain. Budi digambarkan sebagai sosok yang ambisius, energik, juga teledor. Ibu Budi adalah karakter pendukung dalam game ini. Tiap minggu Budi akan menerima sejumlah uang dari Ibu Budi. Ibu Budi digambarkan sebagai sosok yang bijak dan penyayang. 
Selanjutnya aset visual terkait smartphone dibutuhkan untuk memvisualkan aktivitas jual-beli yang bisa dilakukan Budi melalui smartphonenya. Aset visual antarmuka dibutuhkan untuk keperluan perancangan antarmuka.
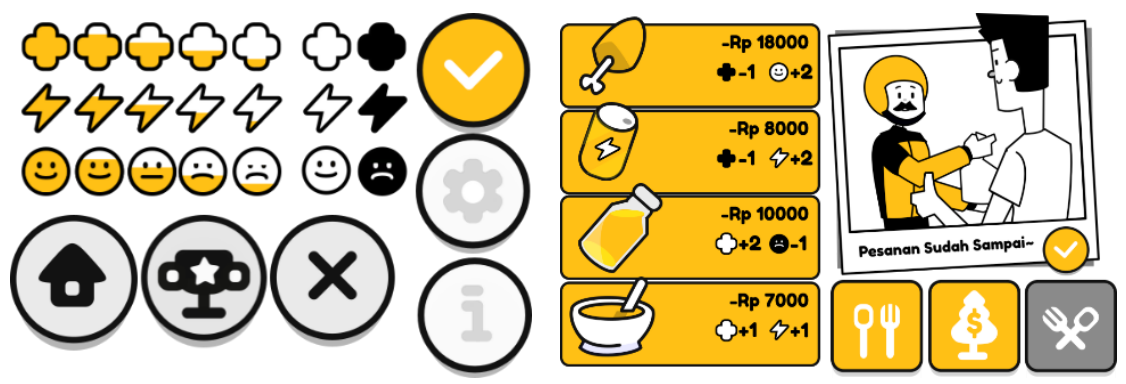

Gambar 6. Aset Visual

[Sumber: Dokumentasi Penulis]

Foto Budi saat Study Tour dibutuhkan untuk memvisualkan tampilan akhir permainan, baik untuk kondisi menang (kiri) maupun kalah (kanan).
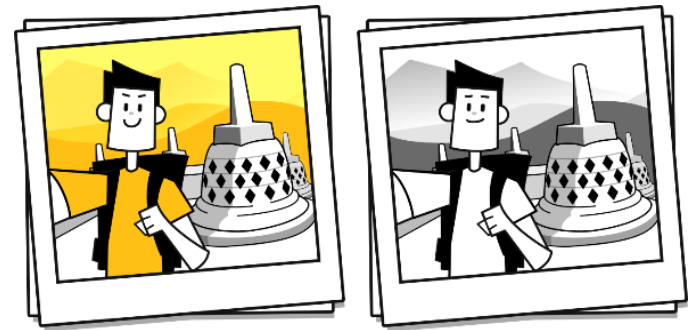

Gambar 7. Ilustrasi Foto Budi saat Study Tour [Sumber: Dokumentasi Penulis]

\subsection{Visualisasi Desain Antarmuka}

Dalam pengembangan game, desain antarmuka dibutuhkan untuk mengarahkan dan memandu pemain selama bermain. Desain antarmuka menunjukkan proses dan alur bermain, memberi informasi yang dibutuhkan oleh pemain selama bermain, serta memudahkan pemain dalam bermain. Penggunaan komposisi tata letak dan penempatan elemen-elemen antarmuka yang tepat dan sesuai konteksnya dapat mempengaruhi pengalaman pemain dalam bermain (Rogers, 2010). Tampilan menu utama yang menampilkan tombol untuk memulai dan melanjutkan permainan, tombol untuk mengakses bagian Awards \& Leaderboard, tombol untuk melihat informasi tentang game, dan tombol mengubah opsi permainan. 


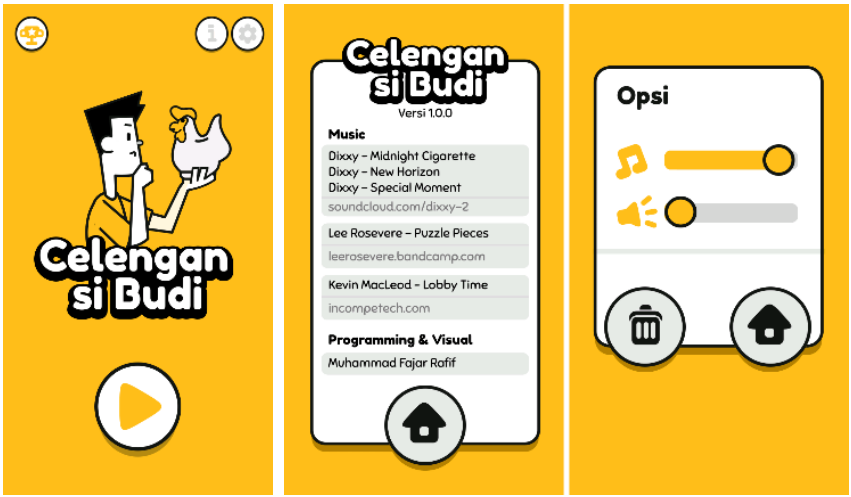

Gambar 8. Tampilan Menu Utama, Tampilan Informasi, \& Tampilan Pengaturan [Sumber: Dokumentasi Penulis]

Tampilan Informasi yang menginformasikan tentang siapa saja yang terlibat dalam proses pembuatan game, serta tombol untuk kembali ke Menu Utama. Tampilan Pengaturan yang menampilkan beberapa aspek yang bisa diatur pemain, antara lain volume efek suara, volume lagu, opsi untuk menghapus proses game agar bisa mulai dari awal, serta tombol untuk kembali ke menu utama. Tampilan Awards yang terdiri dari status poin ' $X P^{\prime}$ ' pemain, daftar tantangan opsional yang bisa diraih oleh pemain, deskripsi tantangan \& ' $X P^{\prime}$ ' yang bisa diperoleh dalam menyelesaikan tantangan, tab untuk mengakses bagian Leaderboard, dan tombol untuk kembali ke menu utama. Tampilan Leaderboard yang terdiri dari status poin ' $X P^{\prime}$ ' pemain, daftar peringkat pemain teratas (berdasarkan ' $X \mathrm{P}^{\prime}$ yang diperoleh), tab untuk mengakses bagian Awards, dan tombol untuk kembali ke menu utama.

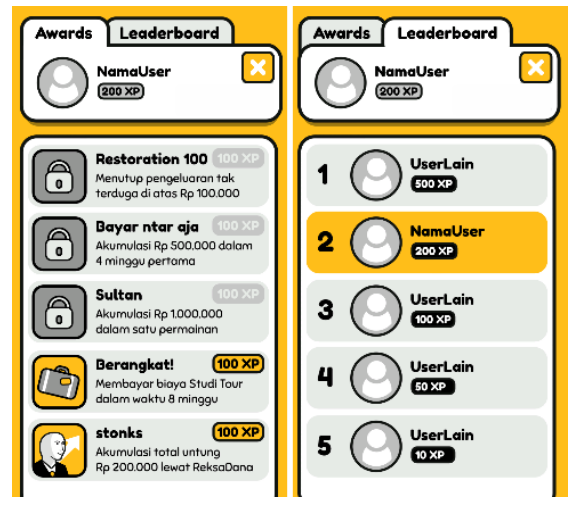

Gambar 9. Tampilan Awards dan Tampilan Leaderboard [Sumber: Dokumentasi Penulis]

Tampilan Awal Hari yang terdiri dari ilustrasi kalender yang menampilkan waktu pada game, tujuh buah lingkaran yang merepresentasikan berapa hari yang telah dilalui pemain dalam satu minggu, dan tombol untuk melanjutkan permainan. Tampilan Awal Hari menunjukkan hasil proses pemain sejauh ini dalam mencapai tujuannya dan secara tidak langsung menunjukkan waktu yang tersisa untuk mencapai tujuannya. Tampilan Narasi Game yang terdiri dari ilustrasi kejadian yang dialami pemain dengan narasi di bawahnya, tombol untuk melanjutkan, dan tombol untuk menampilkan Tampilan Jeda yang terletak di sisi kanan atas. Tampilan Narasi akan seringkali muncul di saat 
permainan, baik sebelum sekolah maupun sepulang sekolah. Kejadian yang dialami bisa berupa informasi mengenai mekanisme game, informasi mengenai keuangan, maupun decision making seputar keuangan.

Tampilan Jeda yang terdiri dari opsi untuk mengubah audio dan musik, tombol untuk melanjutkan permainan, tombol untuk mengakses bagian Awards \& Leaderboard, dan tombol untuk kembali ke Menu Utama. Tampilan Status Keuangan yang mencakup laporan arus kas, yaitu jumlah pemasukan dan sumbernya, jumlah pengeluaran dan sumbernya, dan aset si Budi yang meliputi uang kas, dan portfolio reksadana yang dimiliki.
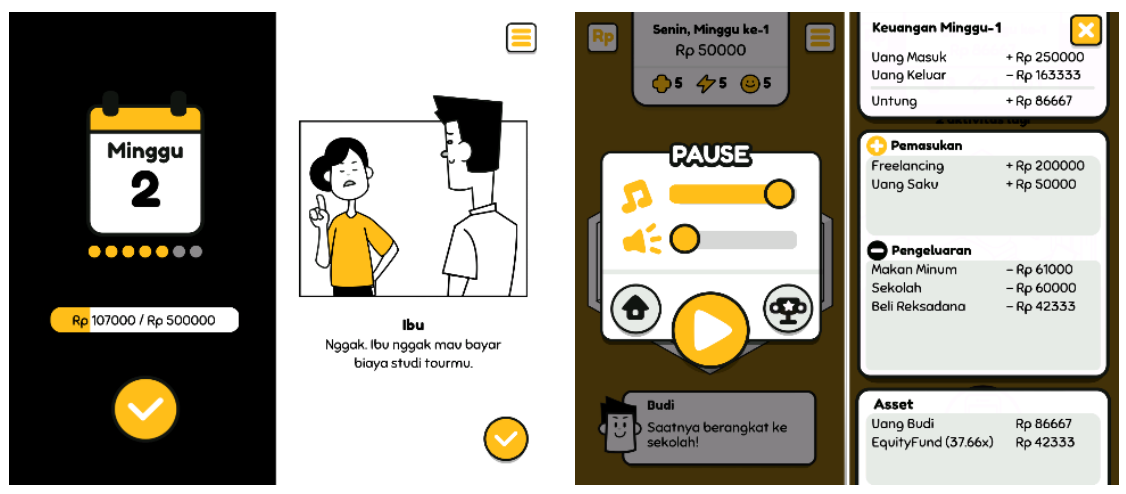

Gambar 10. Tampilan Awal Hari, Tampilan Narasi, Tampilan Jeda, dan Tampilan Status Keuangan [Sumber: Dokumentasi Penulis]

Tampilan Aktivitas Rumah yang terdiri dari ilustrasi kamar budi dan beberapa objek berwarna jingga yang merepresentasikan aktivitas yang bisa dilakukan pemain, informasi mengenai tanggal, uang, informasi kondisi si Budi yg meliputi kondisi kesehatan, tenaga, dan mood, tombol untuk menampilkan Tampilan Jeda yang terletak di sisi kanan atas, dan tombol untuk menampilkan Status Keuangan yang terletak di sisi kiri atas. Tampilan ini muncul sebelum dan sesudah Budi pergi ke sekolah. Sebelum ke sekolah, Budi bisa berangkat ke sekolah menggunakan metode transportasi yang diinginkan. Setelah pulang dari sekolah atau pada hari Sabtu \& Minggu, aktivitas yang bisa dilakukan Budi yaitu jalan-jalan, istirahat, mengakses laptopnya untuk mencari penghasilan secara online, dan mengakses smartphonenya.

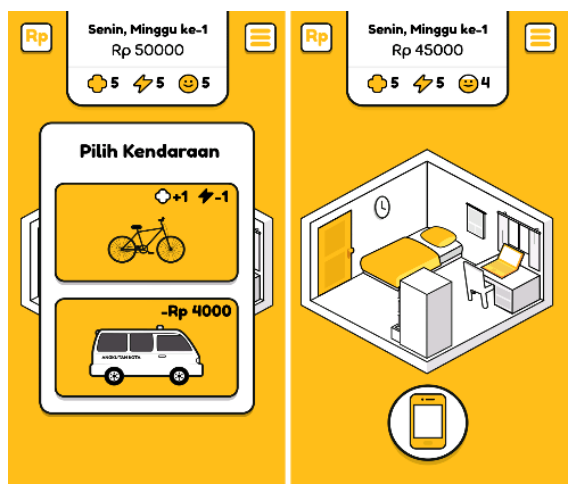

Gambar 11. Tampilan Aktivitas Rumah [Sumber: Dokumentasi Penulis] 
Tampilan Narasi Sekolah yang terdiri dari ilustrasi kejadian yang dialami pemain selama di sekolah, ilustrasi jam yang menunjukkan waktu selama di sekolah, informasi mengenai tanggal, uang, informasi kondisi si Budi, tombol untuk menampilkan Tampilan Jeda yang terletak di sisi kanan atas, dan tombol untuk menampilkan Status Keuangan yang terletak di sisi kiri atas. Selama jam sekolah ada kemungkinan biaya tak terduga maupun perubahan kondisi tak terduga, misalnya Budi membutuhkan buku baru, membutuhkan biaya untuk reparasi sepeda, dan sebagainya.

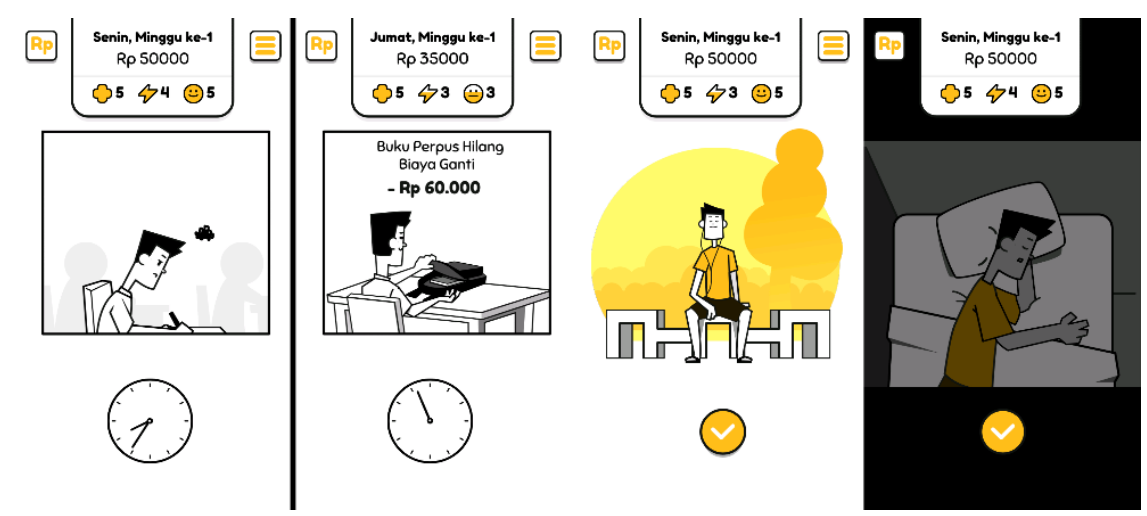

Gambar 12. Tampilan Narasi Sekolah

[Sumber: Dokumentasi Penulis]

Tampilan Aktivitas Jalan-jalan dan Tampilan Istirahat yang terdiri dari ilustrasi aktivitas yang dilakukan oleh pemain, tombol untuk menampilkan Tampilan Jeda yang terletak di sisi kanan atas, dan tombol untuk menampilkan Status Keuangan yang terletak di sisi kiri atas. Tampilan Aktivitas Jalan-jalan muncul ketika pemain mengakses pintu kamar Budi setelah pulang sekolah atau pada saat weekend, sedangkan Tampilan Istirahat muncul setelah pemain melakukan aktivitas jalan-jalan, setelah bekerja secara online, atau ketika pemain mengakses kasur untuk beristirahat.

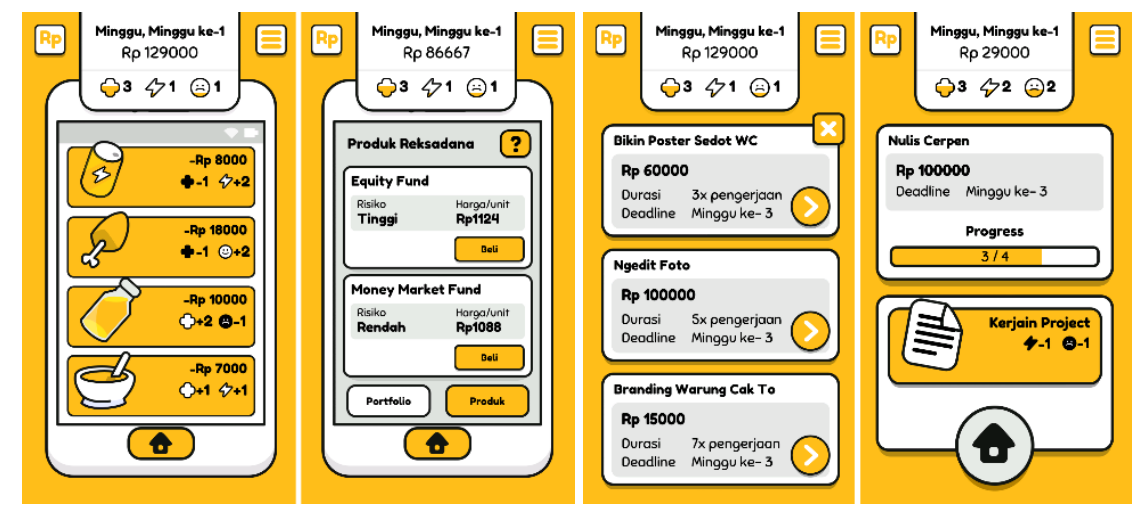

Gambar 13. Tampilan Aplikasi Beli Makan, Aplikasi ReksaDana, Freelancing, dan Tampilan Pengerjaan

[Sumber: Dokumentasi Penulis]

Tampilan aplikasi Beli Makan yang dapat diakses melalui Smartphone Budi, di mana pemain bisa membayar sejumlah uang untuk membeli makanan yang dapat mempengaruhi kondisi Budi.Tampilan aplikasi ReksaDana di mana pemain bisa 
menginvestasikan sejumlah uang untuk produk reksadana dengan resiko yang bervariasi. Di sini pemain bisa melihat perkembangan produk investasi mereka, membeli, dan menjual produk reksadana. Tampilan Freelancing (kerja lepas) yang terdiri dari ilustrasi laptop, informasi mengenai tanggal, uang, informasi kondisi si Budi. Tampilan ini muncul ketika pemain mengakses laptop Budi. Di sini pemain bisa mencari project baru untuk dikerjakan. Tampilan Pengerjaan adalah tampilan Freelancing yang diakses apabila sedang mengerjakan sebuah project.

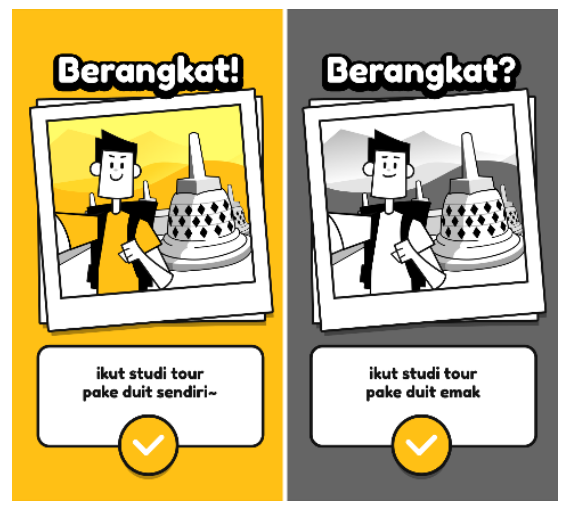

Gambar 14. Tampilan Akhir Menang \& Kalah

[Sumber: Dokumentasi Penulis]

Tampilan Akhir gambar 14 yang muncul di akhir permainan, yang menampilkan ilustrasi Budi di saat study tournya dan menginformasikan bahwa permainan sudah berakhir, menunjukkan bahwa pemain telah mencapai kemenangan/kekalahan, dan tombol untuk kembali ke menu utama.

\subsection{Hasil Pengujian dan Validasi Kelayakan Media}

Setelah purwarupa game siap dimainkan, divalidasikan kepada ahli media, dan ahli materi untuk mengetahui kelayakan game menggunakan instrumen kuisioner skala Likert, dengan klasifikasi penilaian sebagai berikut. Dikategorikan Sangat Layak apabila nilai 4,2 - 5. Layak 3,4 - 4,2. Cukup Layak 2,6 - 3,4. TIdak Layak 1,8 - 2,6. Sangat Tidak Layak $1,0-1,8$.

Tabel 1. Hasil Validasi Ahli Media

[Sumber: Dokumentasi Penulis]

\begin{tabular}{|l|c|c|}
\hline \multicolumn{1}{|c|}{ Indikator } & Jumlah Skor & Rerata \\
\hline Game berjalan dengan lancar tanpa ada kendala teknis & 5 & 5 \\
\hline Game berjalan tanpa bantuan aplikasi tertentu & 5 & 5 \\
\hline Penggunaan bahasa yang komunikatif & 5 & 5 \\
\hline Kemudahan navigasi Game & 5 & 5 \\
\hline Tujuan akhir game tersampaikan dengan jelas & 5 & 5 \\
\hline Tingkat keterbacaan tulisan dalam game & 5 & 5 \\
\hline Kualitas tampilan Audio \& Visual & 4 & 4 \\
\hline Game dapat dikembangkan lagi & 5 & 5 \\
\hline Total & 39 & $\mathbf{4 , 8 7}$ \\
\hline
\end{tabular}


Validasi Ahli Media dilakukan oleh ahli media yang kajiannya berkaitan dengan aspek teknis dan usability. Berikut ini adalah penilaian hasil valiadasi ahli media yang dilakukan oleh Bapak Fadjar Arianto, S.Kom. selaku IT Consultant. Berdasarkan hasil validasi ahli media, dapat disimpulkan bahwa perancangan game 'Celengan si Budi' dari aspek media termasuk dalam kategori 'sangat layak'.

Tabel 2. Hasil Validasi Ahli Materi

[Sumber: Dokumentasi Penulis]

\begin{tabular}{|l|c|c|}
\hline \multicolumn{1}{|c|}{ Indikator } & Jumlah Skor & Rerata \\
\hline Tujuan akhir game disampaikan dengan baik & 5 & 5 \\
\hline Strategi yang digunakan dalam Penyampaian Materi efektif & 4 & 4 \\
\hline Materi mengenai pengenalan Reksadana yang disampaikan valid & 5 & 5 \\
\hline $\begin{array}{l}\text { Materi mengenai pengenalan Dana Darurat yang disampaikan } \\
\text { valid }\end{array}$ & 5 & 5 \\
\hline Game Memberikan Umpan Balik terhadap hasil pembelajaran & 4 & 4 \\
\hline Penyampaian Materi mudah untuk dipahami & 4 & 4 \\
\hline Total & 27 & $\mathbf{4 , 5}$ \\
\hline
\end{tabular}

Validasi Ahli Materi dilakukan oleh ahli materi yang kajiannya berkaitan dengan validitas materi keuangan yang diangkat. Berikut ini adalah penilaian hasil valiadasi ahli materi yang dilakukan oleh Ibu Ita Guntari, CFP selaku Perencana Keuangan. Berdasarkan hasil validasi ahli materi, dapat disimpulkan bahwa perancangan game 'Celengan si Budi' dari aspek materi termasuk dalam kategori 'sangat layak'.

\section{KESIMPULAN}

Melalui perancangan ini, dapat disimpulkan dari hasil ujicoba dan validasi bahwa game selain sebagai media hiburan juga dapat menjadi media pembelajaran yang efektif. Game dapat menjelaskan materi yang abstrak menjadi konkrit dengan menawarkan ruang bagi pemain untuk bereksperimen. Game dapat mengemas sebuah permasalahan yang bisa diselesaikan pemain melalui berbagai macam cara.

Perancangan game adalah langkah yang penting dalam proses pengembangan game, karena perancangan adalah pondasi awal dalam pengembangan game. Apabila pondasi awalnya kurang maksimal, maka seluruh aspek lainnya pun juga ikut jatuh. Berdasarkan feedback dari ahli materi, beberapa bagian game cenderung repetitif dan minim aktivitas yang bisa dilakukan. Saran dalam merancang game edukasi adalah dengan memperkuat dan menggali lebih dalam konsep dan materi game yang diusung agar bisa dikolaborasikan satu sama lain, sehingga dapat menghasilkan pengalaman bermain yang menyenangkan. Melakukan studi kasus terhadap game yang serupa adalah langkah yang tepat untuk mempercepat proses perancangan. Selain itu, perancangan ini hanya sampai pada tahap purwarupa saja, sehingga belum ada produk jadi. Dengan melibatkan proses pengembangan dan peluncuran game, game yang dihasilkan bisa langsung dikonsumsi oleh masyarakat. 


\section{DAFTAR PUSTAKA}

Asosiasi Penyelenggara Jasa Internet Indonesia. (2018). Laporan Survei Penetrasi \& Profil Perilaku Pengguna Internet di Indonesia 2018. In Asosiasi Penyelenggara Jasa Internet Indonesia.

Bisnis.com. (2020). Begini Perubahan Perilaku Konsumen Gara-gara Corona. https://ekonomi.bisnis.com/read/20200414/12/1227101/begini-perubahanperilaku-konsumen-gara-gara-corona

GameLab Indonesia. (2018). Tips Membuat Game Design Document (GDD) Bagi Pemula. GameLab Indonesia. https://www.gamelab.id/news/54-tips-membuat-gamedesign-document-gdd-bagi-pemula

Landa, R. (2011). Graphic Design Solutions 4th Edition. Clark Baxter.

Maulida, L. (2018). Jumlah gamer di Indonesia capai 100 juta di 2020. https://www.tek.id/insight/jumlah-gamer-di-indonesia-capai-100-juta-di2020-b1U7v9c4A

Miles, M. B., \& Huberman, M. a. (2012). Analisis Data Kualitatif: Buku Sumber Tentang Metode-Metode Baru. In Universitas Indonesia_UI Press.

Munir. (2012). Multimedia: Konsep \& Aplikasi dalam Pendidikan. In Pernerbit Alfabeta.

Otoritas Jasa Keuangan. (2019). Siaran Pers Survei OJK 2019: Indeks Literasi Dan Inklusi Keuangan Meningkat. Sp 58/Dhms/Ojk/Xi/2019.

Pratama, E. G. (2017). Mengenal Sekilas Jenis-Jenis Flowchart pada Pemrograman. https://www.codepolitan.com/mengenal-sekilas-jenis-jenis-flowchart-padapemrograman-589be38b9417f

Rogers, S. (2010). Level Up!: The Guide to Great Video Game Design. In John Wiley \& Sons, Ltd.

Schell, J. (2008). The art of game design: A book of lenses. In The Art of Game Design: A Book of Lenses.

Tim GLN Kemendikbud. (2017). Materi Pendukung Literasi Finansial. In Gerakan Literasi Nasional. Kemendikbud. http://gIn.kemdikbud.go.id/gInsite/buku-literasifinansial/

Tulleken, H. (2015). Color in games: An in-depth look at one of game design's most useful tools. 